\title{
Dynamic Stability of Large Embankment Dams and a Case Study
}

\author{
Hasan Tosun ${ }^{1}$ \\ ${ }^{1}$ Eskisehir Osmangazi University, Engineering Architecture Faculty \\ Bati Meselik, Eskisehir, Turkey \\ htosun@ogu.edu.tr
}

\begin{abstract}
Dams constructed on the area with high seismicity have a high-risk potential for downstream life and property. It is a wellknown fact that active faults, which are located close to dam sites, can induce inadmissible deformation in the embankment and may cause instability of the dam and foundation materials. Direct fault movement across the dam foundation can create displacements, which result to more serious problems for embankments and their appurtenant structures. Especially active faults on or near dam sites can cause severe deformation such as slumping, settlement, cracking and slope failures of the embankment. Turkey has so many dams, which are under the influence of near field motion. One of them is Kockopru dam, which has an earthfill embankment with 74-m height from foundation level, located at a distance of $4.5 \mathrm{~km}$ from significant faulting system in the region. This study outlines stability analyses of large embankment dams located on active seismic area, discusses the experience on behavior of large embankment dams located on or near active faults, based on analytical analyses and presents the results of the case study, including a large dam, which is very close to an active fault system. The results show that the embankment is safe for the loading of MDE and SEE condition. For SEE loading condition local sliding problem can occur on both slopes. The author suggests to use the specified response spectrum in modeling fault displacement for dynamic analyses performed by numerical methods.
\end{abstract}

Keywords: Dam, dynamic stability, earthquake, total risk

\section{Introduction}

In general, strong ground shaking can result in the instability of the embankment and loss of strength at the foundations. Earthquakes can result in damages or failures for dam structures, while dams with large reservoirs can induce to earthquakes. Earthquake safety assessment is an important phenomenon in dam engineering and requires more comprehensive seismic studies for understanding the seismic behavior of dams subjected to severe earthquakes. It is a well-known phenomenon that earthquakes can result damages and failures for dams and their appurtenant structures. Wieland [1,2] points out the fact that seismic hazard and seismic design are important aspects for large dam projects. Case studies about the seismic performance of dams under large earthquakes are available in the literature [3-7].

Earthquakes damages to dams may result from direct fault movement across the dam foundation or from ground motion induced at the dam site by an earthquake located at some distance from the dam. There is also another fact that earthquake effect on dam structures mainly depend on their types. Tosun et al [8] stated that safety concerns for embankment dams subjected to earthquakes involve either the loss of stability due to a loss of strength of the embankment and foundation materials or excessive deformations such as slumping, settlement, cracking and slope failures. Safety requirements for concrete dams subjected to dynamic loadings should involve evaluation of the overall stability of the structure, such as verifying its ability to resist induced lateral forces and moments and preventing excessive cracking of the concrete [6].

This study summarizes stability analyses of large embankment dams located on active seismic area, introduces the experience on behavior of large embankment dams located on or near active faults as based on analytical analyses and discusses the results of the Kockopru dam, which is very close to an active fault system.

\section{Material and Methodology}


For seismic hazard analysis of a dam site, the deterministic and probabilistic approaches are commonly used. The deterministic seismic hazard analysis considers a seismic scenario and includes four-step process. It is very simple procedure and gives rational solutions for large dams because of providing a straightforward framework for evaluation of worst ground motions. The probabilistic seismic hazard analysis is widely used and considers uncertainties in size, location and recurrence rate of earthquakes [9]. Due to the unavailability of strong motion records, various attenuation relationships were adopted to calculate the peak ground acceleration (PGA).

ICOLD [10] states that the Maximum Credible Earthquake (MCE) is the largest reasonably conceivable earthquake magnitude that is considered possible along a recognized fault or within a geographically defined tectonic province. In this study, earthquake definitions given by FEMA [11] and DSI [12] were considered for seismic hazard analyses. Most of large dams in Turkey were analyzed by using these definitions in past.

The probabilistic hazard calculation was performed to obtain 5 percent damped elastic hazard pseudo-acceleration spectra and to generate the response spectrum compatible acceleration time histories for time domain analyses. The elastic hazard acceleration spectra on the basis of Boore et al [13] were obtained. For generating the acceleration time histories, a software program TARSCTHS was used [14].

Static and pseudo-static analysis were performed for the case study as based on the simplified Bishop method. A 2D finite element model for the maximum section of the dam and soil profile including bedrock was developed by Plaxis software [15] for the dynamic analysis. Once the model was defined to represent the layered construction technique, then it was modified for dynamic loading conditions. Standard fixity elements were considered along the base and vertical sides of the model. It was assumed that the ground motion acts uniformly along the fixed boundaries.

\section{A case Study-Kockopru Dam}

The Kockopru dam is a zoned earthfill dam on the Zilan River of Van Inner Basin near Ercis County, located in the eastern portion of Turkey. It has a 73.5-m height from foundation (Table 1). Its crest length is $700 \mathrm{~m}$. Kockopru dam with a total embankment volume of 2.02 million cubic meter is located on Zilan river of Van Inner basin. Its construction was finished in 1992. When the reservoir is at operation stage with maximum water level, the facility approximately will impound $86 \mathrm{hm}^{3}$ of water with a reservoir surface area of $21 \mathrm{~km}^{2}$. It was mainly designed to provide water for irrigating a land of 9295 ha and producing electricity with installed capacity of $8.5 \mathrm{MW}$.

Table 1. Properties of Kockopru Dam[16].

\begin{tabular}{|l|c|}
\hline \multicolumn{1}{|c|}{ Properties } & Value \\
\hline Basin & Van Inner \\
\hline Location & East Anatolia \\
\hline Completed Year & 1992 \\
\hline Type & Earthfill dam \\
\hline Purpose & Irrigation and energy \\
\hline Volume of embankment & $2025000 \mathrm{~m}^{3}$ \\
\hline Crest Length & $700 \mathrm{~m}$ \\
\hline Height from river bed & $51.0 \mathrm{~m}$ \\
\hline Height from foundation & $73.5 \mathrm{~m}$ \\
\hline Slopes of embankments & $2.5 / 1$ (Horizontal/Vertical) \\
\hline Downstream & $3.0 / 1$ (Horizontal/Vertical) \\
\hline upstream & $1781 \mathrm{~m}$ \\
\hline Crest level & $1778.5 \mathrm{~m}$ \\
\hline Normal Water level & $21.0 \mathrm{~km}^{2}$ \\
\hline Reservoir Area & $86.0 \mathrm{hm}^{3}$ \\
\hline Total reservoir capacity & $65.0 \mathrm{hm}^{3}$ \\
\hline Active reservoir capacity & \\
\hline
\end{tabular}


The Kockopru dam is a zoned earthfill dam with a central core material. The embankment is mainly composed of clayey material at center and coarse grained material on the shells. There is a transition section of sand between impervious and pervious zones in the embankment. The shells were supported with crushed rock materials on toes of embankment for both side. The side slopes of main embankment are 3.0H:1V for upstream and $2.5 \mathrm{H}: 1 \mathrm{~V}$ for downstream. The slopes of central clay are more stiff $(1 \mathrm{H}: 1 \mathrm{~V})$ and have same value. The main element of embankment is pervious sandy gravel. This material has good quality when considered abrasion and frost resistance.

\section{Analyses and Results}

\subsection{Seismic Hazard and Total Risk Analyses}

The seismic hazard analysis was performed for the dam by means of two separate methods. The deterministic seismic hazard analysis shows that the PGA values for 50 percentile range from $0.239 \mathrm{~g}$ to $0.325 \mathrm{~g}$ while those for 84 percentile are between $0.405 \mathrm{~g}$ and $0.594 \mathrm{~g}$. Their averages are very close to Boore's relationship. Therefore, they are considered as $0.283 \mathrm{~g}$ and $0.481 \mathrm{~g}$ for 50 and 84 percentiles, respectively. The seismo-tectonic model and earthquakes are given in Figure 1.

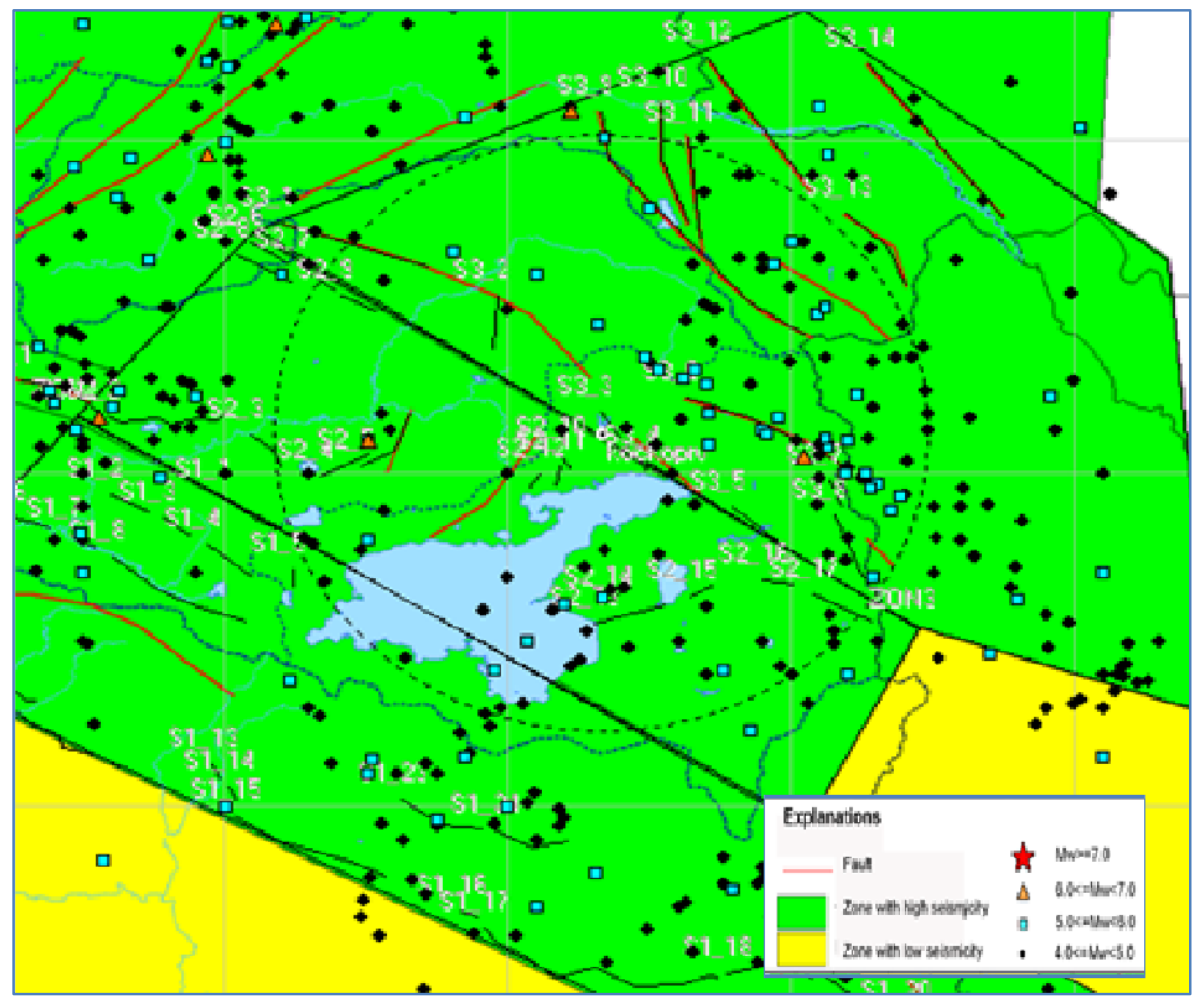

Figure 1. Seismo-tectonic Model and Earthquakes

The results of probabilistic seismic hazard analysis indicate that peak ground acceleration (PGA) changes within a wide range for all earthquakes levels. For OBE, MDE and SEE (for 2475 years), the PGA value was considered as $0.448 \mathrm{~g}, 0.570 \mathrm{~g}$ and $0.750 \mathrm{~g}$, respectively. As based on this study, Total Risk Factor (TRF) value is 197.68 and it is identified as risk class of III [17]. It means that it has "high risk" potential for downstream life and structures. According to the risk classification adopted by DSI [12], It is categorized as class III with high risk. The seismic hazard analyses performed throughout this study indicates that Kockopru dam is one of the critical dams within the Van Inner Basin of Turkey. 


\subsection{Static and Pseudo-Static Analyses}

Static and pseudo-static analysis are the simplest method to analyse the static and dynamic behavior soil embankments. The choice of seismic coefficients used in the analyses can be questionable. For this study slopes of embankment were studied for separate loading conditions. Along a critical slip surface through the embankment or through the embankment and its foundation, the total driving and total resisting forces are determined and the factor of safety against stability failure was calculated for each loading case. The calculated value should provide the minimum value given in the specification. For end-of-construction and operation stages, the static slope stability analysis is evaluated for downstream and upstream slopes separately. In the case of operation downstream slope was analyzed considering the maximum water level, while upstream slope is evaluated under partial reservoir condition. The upstream slope was also analyses for rapid drawdown condition.

The seismic stability of both slopes were also evaluated based on the peak ground acceleration for end-of construction and operation stages. Tosun [17] summarizes the upgraded principles of static and pseudo-static stability analysis for embankment dams, introduces most common approaches for determining the properties of fill materials and foundation soils and mentions the factor of safety concept for each case.

For this study, earth fill stability of Kockopru dam have been investigated as defining a factor of safety for different loading condition by means of static and pseudo-static analysis (Table 2). At the beginning of this study, seismic coefficient was determined for pseudo-static analysis as based on the approach given in Tosun (2018). According to this approach seismic coefficient ranges from 0.15 to 0.20 . For this study, it was selected as 0.20 . Analyses have been executed by means of a software, namely GSTABIL7. The safety factors were calculated by the Modified Bishop Method. The value of seismic coefficient $(\mathrm{k})$ was determined as 0.22 for limit equilibrium condition $\left(\mathrm{F}_{\mathrm{S}}=1.0\right)$. An example from analyses is introduced in Figure 2.

Table 2. Safety factors of pseudo-static analysis for separate loading conditions

\begin{tabular}{|l|l|l|c|c|}
\hline Case & Description & Slope & \multicolumn{2}{|c|}{ Factor of Safety } \\
\cline { 4 - 5 } & & & Required & \multicolumn{2}{|c|}{ Calculated } \\
\hline I & End-of & Downstream & 1.3 & 1.99 \\
& Construction & Upstream & $1.1-1.3$ & 2.80 \\
\hline II & Rapid drawdown & Upstream & & 2.16 \\
\hline III & & & $1.4-1.5$ & 2.01 \\
& Operation & Downstream & & 2.20 \\
\hline & & Upstream & & 1.22 \\
IV & & End-of-Construction & & 1.62 \\
& \multirow{3}{*}{ Earthquake } & Downstream & & 1.20 \\
& & Upstream & & 1.05 \\
\hline
\end{tabular}

The minimum factor of safety was obtained as 1.05 for upstream slope at earthquake loading condition. However, local slope damages can be seen for downstream side even if it provides the required value given in the specification. From the results, it can be stated that the dam is almost safe during the earthquake when we use k-value, which is based on the conventional method [18]. However, it is not safe according to the pseudo-static analyses for earthquake loading conditions when considered the seismic coefficient based on the risk classification as given on DSI Specification [19]. 


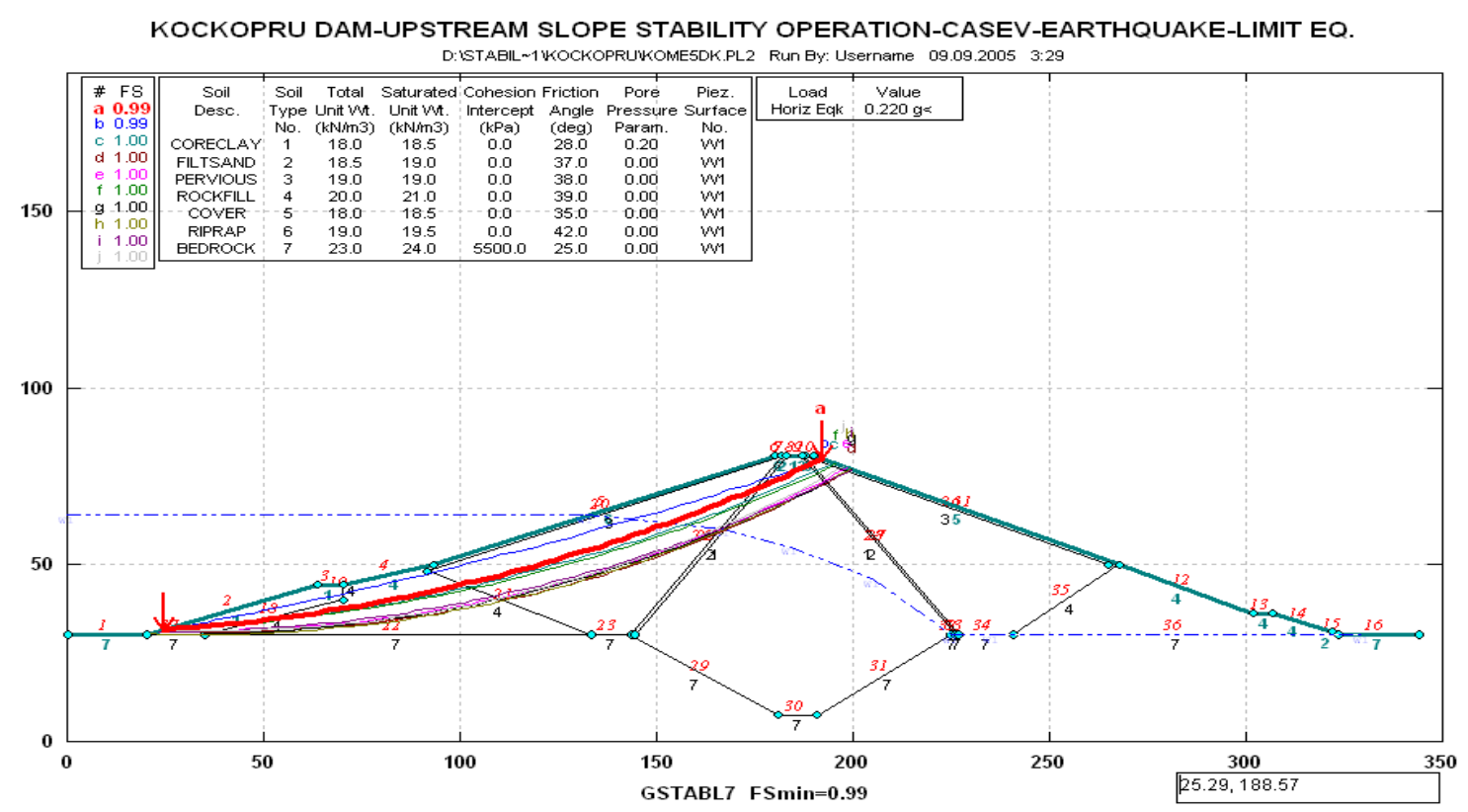

Figure 2. An example of slope stability analyses for Kockopru dam embankment

\subsection{Numerical Analyses}

The two-dimensional finite element model for the maximum section of the dam and soil profile including bedrock is given in Fig. 3. The model consisted of 5466 nodal points, 9948 stress points and seven cluster elements. Standard fixity elements were considered along the base and vertical sides of the model. It was assumed that the ground motion acts uniformly along the fixed boundaries. The Mohr-Coulomb model was selected to define soil properties for all models discussed here.

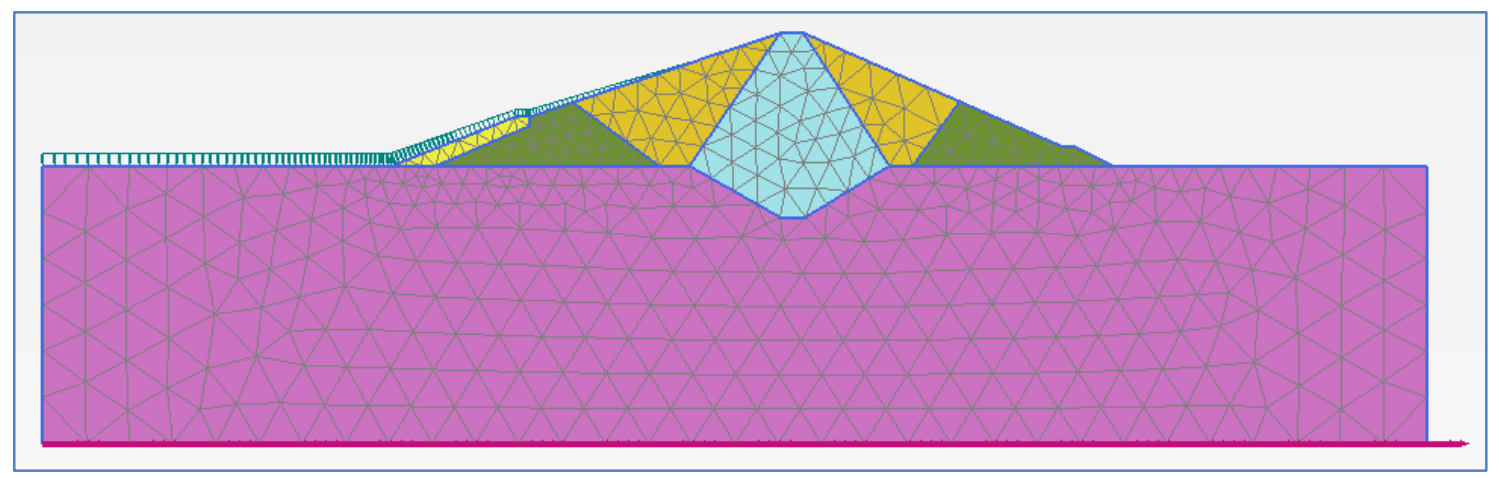

Figure 3. The Finite Element Model of the Embankment of Kockopru dam

The finite element model used in this study is composed of five different materials. The bedrock is also considered as a rigid element with high deformation modulus. The parameters used in the model were considered from the laboratory tests and the literature survey [20-22]. For the analysis, the deformation moduli of impervious zone and semi-pervious zone were taken into account as 50000 and $85000 \mathrm{kPa}$, respectively.

Figure 4 shows loading conditions of the model. It means that it defines operation stage under steady state condition. The deformed mesh (scaled up 2000 times) is introduced in Figure 5 for MDE loading condition. 


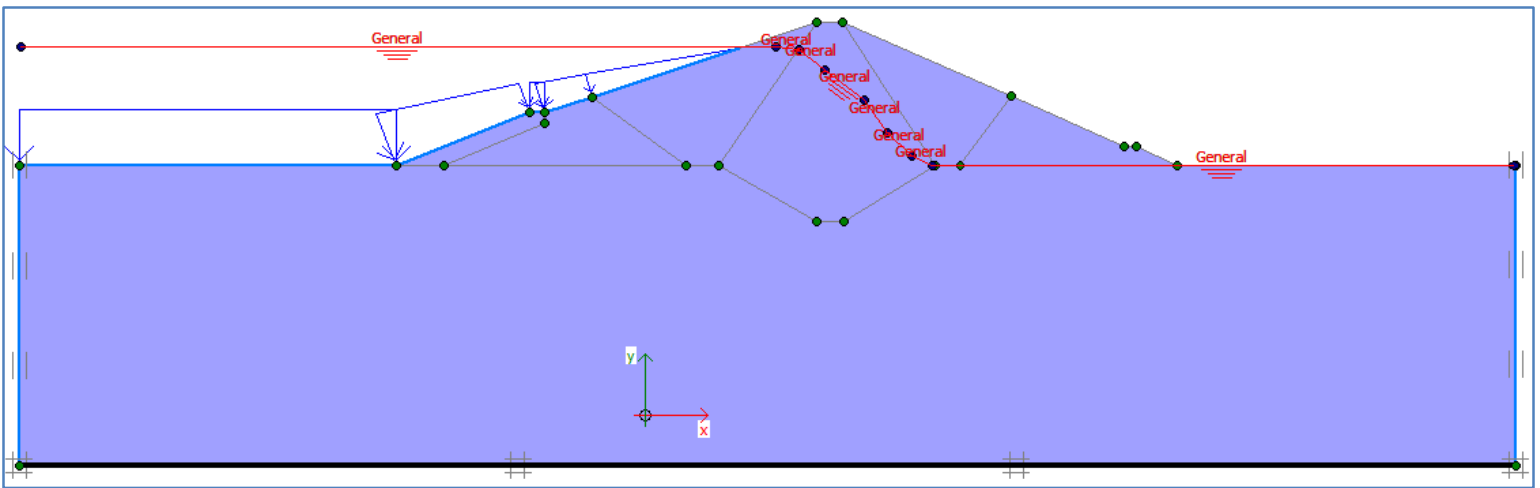

Figure 4. Loading conditions of the model for operation stage.

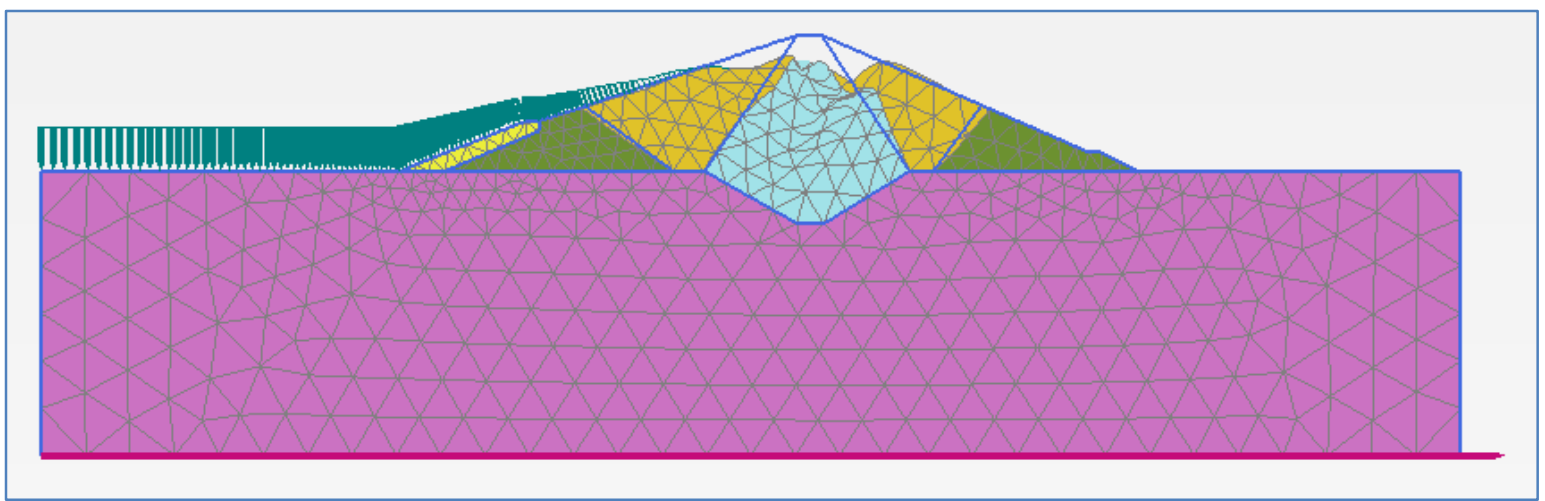

Figure 5. Deformed mesh for MDE loading (scaled up 2000 times)

Figure 6 shows distribution of total vertical displacement of embankment after water impounding for MDE loading condition. The specification states that MDE loading condition should be considered for representing operation stage of embankment. The analysis indicates that maximum values of permanent displacement is 1.0 and $2.3 \mathrm{~cm}$ on the crest of embankment for OBE and MDE loading condition, respectively.

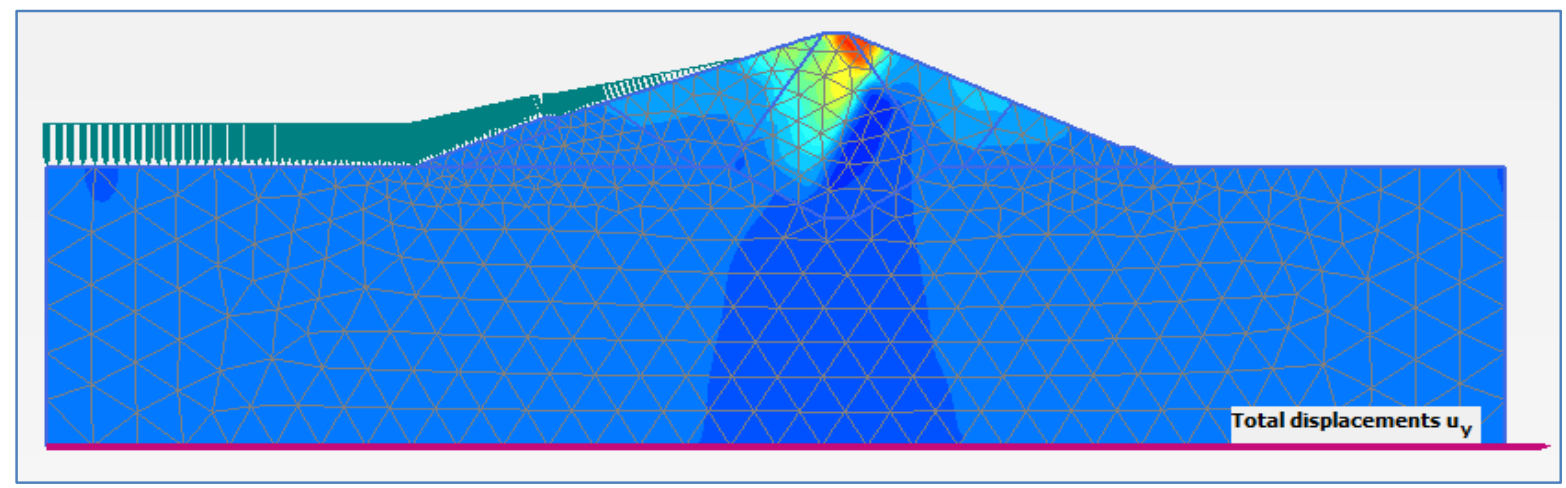

Figure 6. Distribution of vertical displacement for MDE loading condition. 


\section{Discussions}

The pseudo-static analysis indicates that both slopes of embankment are safe. The value of seismic coefficient was obtained as 0.22 for limit equilibrium condition. As a result of numerical analysis, maximum permanent settlement was predicted as $2.3 \mathrm{~cm}$ for dynamic loading of MDE level, when used the Mohr-Coulomb material type. The permeant vertical and horizontal displacement are too much when considered for soil-hardening material type. Stage for water impounding is taken into account for MDE analyses. Author and co-workers had so many experience in determining seismic hazard and total risk of dam sites and analyzing embankment dams with numerical modelling [23-41].

By finite element analysis, displacements are controlled for different sections. The distribution of horizontal and vertical displacements for a selected section can be obtained after OBE and MDE loading. For Kockopru dam vertical displacement increases towards the crest. However, maximum horizontal displacements occur on the mid-level of slopes.

The critical slip surfaces are generally passing through toe of embankment when executed analyses for total and effective stress conditions. Peak ground acceleration on crest ( $\mathrm{a}_{\text {maks }}$ ) was obtained as $0.60 \mathrm{~g}$ from the analysis for MDE loading. The maximum seismic coefficient ( $\mathrm{k}_{\text {maks }}$ ) was determined as 0.22 from pseudo-static analysis. Their ratio ( $\left.\mathrm{a}_{\text {maks }} / \mathrm{k}_{\text {maks }}\right)$ was calculated as 0.36. According to Makadisi and Seed [42], displacement range from 5 to $10 \mathrm{~cm}$. These values obtained from empirical approximation confirm data given by numerical methods. The displacement values obtained from numerical method provides the limitations given in literature $[11,19]$.

\section{Conclusions}

Kockopru dam site, which is located on one of the complicated geological and seismological region of Turkey, is under near field motion according to the seismic data. The slopes of embankment are safe when considered the pseudo-static analyses, when we use the conventional technique for obtaining the seismic coefficient. The dynamic analysis of twodimensional finite element model of dam-foundation system indicates that the maximum value of displacement is only 2.3 $\mathrm{cm}$ on the crest under the loading of Maximum Design Earthquake. The permanent deformation for this model was obtained around 5 to $10 \mathrm{~cm}$ by means of semi-empirical methods. These results indicate that the embankment is safe for the loading of MDE and SEE condition. For SEE loading condition local sliding problem can occur on both slopes. However, the specified response spectrum modeling fault displacement should be considered for dynamic analyses performed by numerical methods.

\section{References}

[1] M. Wieland, "Seismic design of major components," International Water Power and Dam Construction, February 1619, 2013.

[2] M. Wieland, "Seismic hazard and seismic design and safety aspects of large dam projects," in Proceedings of the Second European Conference on Earthquake Engineering and Seismology, Istanbul, 2014, Aug. 25-29.

[3] H.B.Seed, K.L Lee, I.M.Idriss and F.I. Makdisi, "The slides in the San Fernando Dams during the earthquake of February 9, 1971, " Journal of the Geotechnical Engineering Division, ASCE 101(GT7), 651-688, 1975.

[4] B.L.Bell and A. Nur, "Strength changes due to reservoir-induced pore pressure and stresses and application to Lake Oroville”, J. Geophys. Res. 83, 4469-4483, 1975.

[5] G.P. Castro and S.J. Poulos and F.D.Leathers, "Re-examination of slide of Lower San Fernando Dam”, ASCE, Journal of Geotechnical Engineering 111. J. Geophys. Res. 83, 4469-4483, 1985.

[6] R.B.Jansen, (ed.) “Advanced Dam Engineering for Design, Construction and Rehabilitation", Van Noswtrand Reinhold, New York, 1988, 884p.

[7] H.Tosun, "Earthquakes and Dams", in Earthquake Engineering-Seismology to Optimal seismic design of engineering structures (edited by A. Moustafa), Intec Publication ISBN 978-953-51-2039-1, 2015.

[8] H.Tosun, I.Zorluer, A.Orhan, E.Seyrek, H.Savaş, and M.Türköz, "Seismic Hazard and Total Risk Analyses for Large Dams in Euphrates Basin, Turkey". Engineering Geology, 2007, 89, 155-170.

[9] S.L. Kramer, “Geotechnical Earthquake Engineering”, Prentice-Hall, Upper Saddle River, NJ. 653 pp, 1996.

[10] ICOLD, “Selecting Seismic Parameters for Large Dams-Guidelines”, ICOLD Bulletin 148, 2016. 
[11[ FEMA, "Federal Guidelines for Dam Safety-Earthquake Analyses and Design of Dams" 2005.

[12] DSI, "Selection of Seismic Parameters for Dam Design”, State Hydraulic Works, Ankara, 29 p, 2012 (in Turkish).

[13]D.M.Boore, W.B.Joyner \& T.E.Fumal, "Equation for Estimating Horizontal Response Spectra and Peak Acceleration from Western North American Earthquakes". A Summary of recent Work. Seismological Research Letters, V.68, N.1, January /February, 128-153, 1997.

[14] A.Papageorgiou, B.Halldorsson and G.Dong, "Target Acceleration Spectra Compatible Time Histories", University of Buffalo, Dept. of Civil, Structural and Environmental Engrg., NY, 2000.

[15] Plaxis, "V8 Professional Version-User Manual" (Edited by Brinkgreve, R.B.J., Broere, W., and Waterman, D.), Netherlands, 2008.

[16] DSI, “Dams of Turkey”, TR-COLD, Ankara, 2016, 602 p.

[17] G.J. Bureau, "Dams and Appurtenant Facilities in Earthquake Engineering Handbook", edited by Chenh, W.F and Scawthorn,C. CRS press, Bora Raton, 2003, 26.1-26.47.

[18] H.Tosun, "Input Parameters and Main principles of Slope Stability Analysis for Embankment Dams", $5^{\text {th }}$ International Symposium On Dam Safety, 27-31 October 2018, İstanbul. (in Turkish).

[19] DSI, “Design Guide for embankment dams", State Hydraulic Works. Ankara, 142 p, 2012 (in Turkish).

[20] H.B. Seed, R.T.Wong, J.M.Idriss and K. Tokimatsu, "Moduli and damping factors for dynamic analysis of cohesionless soils", Report No: UCD/EERC-84-14, Earthquake Engineering Center, University of California, 1984.

[21] G. Hunter, and R.Fell, "Rockfill modulus and settlement of concrete faced rockfill dams", J. Geotech. And Geoenvir. Engrg. 129, 2003.

[22] R.P.Brenner, M.Wieland and S.Malla, "Large-diameter cyclic triaxial tests for seismic safety Assessment", 16 th ICSMGE, Osaka, 2005.

[23] H. Tosun, "Seismic studies”, International Water Power \& Dam Construction, 58 (2), 20-23, 2006.

[24] H.Tosun, "Total Risk Analysis of Dam and Appurtenant Structures in a Basin and a Case Study" International Congress in River Basin Management, Volume I, 22-24 March, Antalya, 477-488, 2007.

[25] H. Tosun, "Evaluating Earthquake Safety for Large Dams in Southeast Turkey", Hydro Review Worldwide (HRW), 3440, 2008.

[26] H.Tosun, "Re-analysis of Ataturk Dam under Ground Shaking by Finite Element Models", in Proceeding of CDA Annual Conference, September 22-27. Saskatoon, Canada, 2011.

[27] H.Tosun, "Earthquake Safety of Keban Dam, Turkey", in Proceeding of CDA Annual Conference, October 15-20. Fredericton, NB, Canada, 2012.

[28] H.Tosun, "Seismic Stability of Large Dams Located Near Energy Source and A Case Study" in Proceeding of 5th International Conference on Earthquake Engineering and Seismology, METU-Ankara 8-11 October 2019.

[29] H Tosun, T.V Tosun "Dynamic Analysis of Embankment Dams Under Strong Seismic Excitation and a Case Study", in Proceeding of Long-Term Behaviour and Environmentally Friendly Rehabilitation Technologies of Dams (LTBD 2017), Tehran, 2017, https://doi.org/10.3217/978-3-85125-564-5-102.

[30] H.Tosun and S. Oguz, "Seismic Design for Existing Large Dams and Case Studies" in Proceeding of $11^{\text {th }}$ ICOLD European Club Symposium Chania, Crete, 2-4 October 2019.

[31] H.Tosun,M. Türkoz, H.Savas and E.Seyrek, River basin risk analysis. Int. Water Power and Dam Construction, May Issue, 2007.

[32] H.Tosun, T.V.Tosun, Total risk and seismic hazard analyses of large dams in northwest Anatolia, Turkey. ICOLD $85^{\text {th }}$ Annual Meeting, July 3-7, Prague, 2017.

[33] H.Tosun, T.V.Tosun, M.A. Hariri-Ardebili, "Total risk and seismic hazard analysis of large embankment dams: case study of Northwest Anatolia, Turkey" Life Cycle Reliability and Safety Engineering, 1-10, 2020 (https://doi.org/10.1007/s41872-020-00113-4).

[34] H.Tosun, H.Savas, "Seismic hazard analyses of concrete dams in Turkey", in Proceeding of CDA Conference, 2005.

[35] H.Tosun, M.Turkoz, "Total risk-analyzing methods for dam structures and a case study in Turkey", in Proceeding of CDA Annual Conference, 2007. 
[36] H.Tosun, E.Seyrek, “Total risk analyses for large dams in Kizilirmak basin, Turkey”, Natural Hazards and Earth System Sciences, 10 (5), 979, 2010.

[37] E.Seyrek, H.Tosun, "Deterministic approach to the seismic hazard of dam sites in Kiz1lırmak basin, Turkey" Natural hazards, 59 (2), 787, 2011.

[38] E.Seyrek, H.Tosun, "Influence of analysis methods for seismic hazard on total risk of large concrete dams in Turkey", Gazi Univ, J.Fac Engineering Architecture, 28-1, 67-75, 2013.

[39] H.Tosun, S.Oguz, "Stability Analysis of Atatürk dam, Turkey as Based on the Updated Seismic Data and Design Code", in Proceeding of 85th Annual Meeting of International Commission on Large Dams, Prague, 66-66, 2017.

[40] H.Tosun, T.V Tosun "Dynamic Analysis of Embankment Dams Under Strong Seismic Excitation and a Case Study", in Proceeding of Long-Term Behaviour and Environmentally Friendly Rehabilitation Technologies of Dams (LTBD 2017), Tehran, 2017, https://doi.org/10.3217/978-3-85125-564-5-102.

[41] H.Tosun, "Re-evaluation of Large Dams in Van Inner Basin, Turkey" 5th World Congress on Civil, Structural, and Environmental Engineering (CSEE'20, Virtual Conference, October 2020 https://doi.org/10.11159/icgre20.192

[42] F.I. Makadisi and H.B. Seed, "Simplified procedure for estimating dam and embankment earthquake-induced deformations", J. Geotech. Eng. Div. ASCE, 1978, 104(7): 849-867. 